DOI: https://doi.org/10.18371/fp.3(39).2020.215180

УДК 657: 004

\title{
ВИКОРИСТАННЯ ІНФОРМАЦІЙНИХ ТЕХНОЛОГІЙ І СИСТЕМ В ОБЛІКУ ТА УПРАВЛІННІ ЕКОНОМІЧНОЮ БЕЗПЕКОЮ ПІДПРИЄМСТВ В УМОВАХ ДІДЖИТАЛІЗАЦІї
}

\author{
ГНЕДІНА Катерина Володимирівна, \\ кандидат економічних наук, дочент, \\ доиент кафедри бухгалтерського обліку, оподаткування та аудиту, \\ Національний університет "Чернігівська політехніка» \\ ORCID ID: http://orcid.org/0000-0001-9471-0932 \\ e-mail:gkv2015oa@gmail.com
}

\section{НАГОРНИЙ Павло Володимирович, здобувач вищої освіти, Національний університет «Чернігівська політехніка» ORCID ID: http://orcid.org/0000-0002-8311-2491 e-mail:inn5665@gmail.com}

Анотація. У статті досліджено особливості впровадження та використання інформаційних технологій і систем для ведення обліку та управління економічною безпекою підприємств. Особливу увагу приділено висвітленню ключових аспектів використання програмного забезпечення ЕRP-класу. Розглянуто переваги та недоліки використання найбільш поширених зарубіжних та вітчизняних інформаційних систем, а також можливості застосування хмарних технологій в обліку та управлінні підприємствами. Визначено перспективи використання украйнських інформаційних систем для автоматизачії ведення бухгалтерського обліку та управління економічної безпекою підприємств в умовах діджиталізації.

Ключові слова: бухгалтерський облік, автоматизація обліку, управління підприємством, управління економічною безпекою, інформаційні технології, інформаційні системи, ЕRР-система, хмарні технологіï, діджиталізаиія.
Аннотация. B cmaтье исследованы особенности внедрения и использования информачионных технологий и систем для ведения учёта и управления экономической безопасностью предприятий. Особое внимание уделено освещению ключевых аспектов использования программного обеспечения ERPкласса. Рассмотрены преимущества и недостатки использования наиболее распространённых зарубежных и отечественных информационных систем, а также возможности применения облачных технологий в учёте и управлении предприятиями. Определены перспективы использования украинских информационных систем для автоматизаичи ведения бухгалтерского учёта и управления экономической безопасностью предприятий в условиях диджитализаџии.

Ключевые слова: бухгалтерский учёт, автоматизаџия учёта, управление предприятием, управление экономической безопасностью, информационные технологии, информационные системы, ERP-система, облачные технологии, диджитализачия. 
Постановка проблеми. Станом на 2019 рік в Україні зареєстровано 1941701 суб' єктів господарювання [1]. При цьому за 2010-2019 роки кількість суб'єктів господарювання жодного разу не була нижчою за 1000000 [1]. Така значна кількість різноманітних суб'єктів господарювання свідчить про високий рівень підприємницької активності в Україні. Зазначені суб'єкти господарювання відрізняються один від одного за видами економічної діяльності, але усіх їх об'єднує необхідність ведення бухгалтерського обліку. Облік необхідний не тільки 3 позицій формування та подання щорічної звітності, але й в управлінській сфері, адже раціонально прийняті рішення на основі даних бухгалтерського обліку дозволяють трансформувати виробничий процес 3 метою мінімізації витрат, максимізації прибутку, досягнення поставлених цілей тощо. Проте чим більший розмір має підприємство, чим значніші обсяги його діяльності, тим більшу сукупність даних обліку доводиться обробляти та зберігати. За певних масштабів діяльності ручне ведення бухгалтерського обліку супроводжується все більшими ризиками виникнення помилок при обробці інформації, зростанням часу на ії обробку та проблемою зберігання. Теперішні часи у науковій періодиці характеризуються як часи глобальної діджиталізації, стрімкого розвитку інформаційних технологій та систем. Їх всебічне впровадження не оминуло стороною і сферу бухгалтерського обліку, внутрішнього контролю та управління підприємством, зокрема - економічною безпекою. У найбільшій мірі зазначене характеризує підприємства Свропи та США, де ручний спосіб обробки облікової інформації фактично майже не використовується. В Україні на деяких підприємствах (у першу чергу, на малих) облік ведеться або взагалі без використання інформаційних технології, або з використанням MS Excel, який не є спеціалізованим програмним забезпеченням у сфері бухгалтерського обліку та дозволяє виконувати лише обмежений спектр операцій, через що складнішою стає процедура формування звітності, втрачаються потенційні можливості вдосконалення ведення операційної діяльності та не використовуються резерви підвищення економічної безпеки підприємств. Це, у свою чергу, зумовлює необхідність впровадження спеціалізованого програмного забезпечення з метою автоматизації обліково-аналітичного процесу на вітчизняних підприємствах. Саме тому доцільним та своєчасним $є$ огляд сучасних інформаційних технологій для автоматизації обліку та управління економічною безпекою, а також визначення перспектив їх подальшого впровадження і використання на вітчизняних підприємствах.

Аналіз останніх досліджень і публікацій. Проблеми впровадження та використання інформаційних технологій у системі бухгалтерського обліку та управлінні на вітчизняних підприємствах висвітлено у працях таких вчених, як: Ф.Ф. Бутинець, В.М. Гужва, В.П. Завгородній, В.І. Ісаков, Ю.А. Кузьмінський, С.В. Мельниченко, Т.В. Моряк, Т.А. Писаревська, Р.В. Скалюк, Н.Г. Твердохлєб, В.В. Чудовець, С.В. Шевченко, В.Д. Шквір. та багатьох інших. Різним аспектам застосування інформаційних систем для автоматизації ведення обліку та складання фінансової звітності на великих підприємствах приділена 
увага таких дослідників, як: С.М. Белінська, В.П. Волков, О.О. Гудзовата, В.В. Муравський, Т.В. Пономарьова. Особливості автоматизації обліку на малих підприємствах досліджуються у наукових роботах таких вчених: Н.М. Бондаренко, О.I. Волот, К.І. Зеленська, М.І. Кітченко, Ю.Б. Скорнякова, М.А. Саєнсус, С.В. Шевченко та інших.

Виділення недосліджених частин загальної проблеми. Темпи розробки нового та модернізації вже існуючого програмного забезпечення завжди випереджають темпи його інтеграції на підприємствах. Саме тому питання дослідження новітніх розробок у сфері автоматизації обліку та управління підприємствами, визначення переваг, недоліків та перспектив їх використання на вітчизняних підприємствах $\epsilon$ актуальним та своєчасним в умовах діджиталізації та становлення безконтактної економіки. У вітчизняних реаліях вказане питання $є$ особливо важливим у зв'язку з пошуком найкращих альтернатив забороненим до використання у 2017 році програмним продуктам [2]. Крім того, малодослідженими залишаються особливості застосування хмарних технологій у системі обліку та управління підприємством та потребують визначення перспективи їх використання вітчизняними підприємствами.

Метою статті полягає в аналізі та порівнянні можливих варіантів автоматизації бухгалтерського обліку та управлінні економічною безпекою на підприємствах України шляхом використання сучасних інформаційних технологій, а також виокремленні основних переваг та недоліків, можливих ризиків інтеграції та застосування даних інформаційних технологій і систем.
Для досягнення поставленої мети у науковій роботі було поставлено та вирішено такі завдання:

- визначити основні переваги та недоліки застосування інформаційних систем автоматизації обліку та управління підприємством;

- охарактеризувати основні особливості застосування систем ERPкласу;

- порівняти доцільність використання зарубіжних та вітчизняних інформаційних систем для автоматизації обліку та управління підприємством;

- оцінити перспективи застосування хмарних технологій у сфері бухгалтерського обліку та управління економічною безпекою підприємства.

Виклад основних результатів. Інформаційна система (IC) бухгалтерського обліку - організаційно оформлена сукупність інформаційних потоків, документів, каналів зв'язку і технічних засобів, яка організовує пам'ять i маніпулювання інформацією щодо показників всіх або деяких форм звітності підприємства [3]. Впровадження інформаційних систем бухгалтерського обліку надає низку переваг підприємству, серед них: підвищення якості обробки інформації та своєчасність цього процесу, формування інформаційної бази щодо внутрішнього та зовнішнього середовищ підприємства, можливості збереження значного обсягу інформації та іiї відновлення у разі потреби, спрощений обмін інформацією між департаментами та фахівцями, накопичення та систематизація інформації, створення передумов для проведення аналізу результатів діяльності підприємства, формування усіх необхідних документів та інші [4].

$\mathrm{y}$ той самий час автоматизація ведення обліку та управління підприєм- 
ством призводить до появи деяких ризиків, зокрема: можливість втрати важливої інформації через іiі збереження у цифровому форматі, складний для користувача інтерфейс та потреба у додаткових фахівцях, тривалість та значні витрати на впровадження та перехід від однієї IC до іншої, ризик несанкціонованого доступу до даних у мережі, загроза зниження попиту на фахівців, які ведуть облік традиційним способом, не використовуючи автоматизовану форму [5].

Для використання сучасних інформаційних технологій і систем 3 метою ведення обліку та управління підприємство потребує фахівців, які б володіли цифровими навичками та постійно вдосконалювали свої знання у сфеpi використання програмних продуктів. Саме тому дуже важливими є розвиток та вдосконалення цифрових навичок та підвищення цифрової грамотності у фахівців з ведення обліку. Під цифровою грамотністю розуміємо «досконале користування електронними засобами, сформованість умінь та навичок роботи 3 «цифрою» [6]. Бухгалтер майбутнього - досвідчений управлінець, аналітик, стратег, вільний користувач спеціалізованого програмного забезпечення для ведення обліку та управління підприємством. Для досвідченого фахівця з обліку необхідними $є$ математичні здібності; знання методів аналізу та синтезу; розуміння, а не механічне повторення; грунтовні знання сучасних інформаційних систем автоматизації обліку та управління підприємством, розуміння їх переваг та недоліків [6]. Світ інформаційних технологій розвивається надто швидко. Тому однією з найважливіших компетенцій бухгалтера май- бутнього є здатність до самоосвіти, у тому числі у сфері використання інноваційних інформаційних систем.

Перейдемо до розгляду базових інформаційних систем автоматизації обліку та управління підприємством. Основний широко застосовний тип автоматизованих інформаційних систем у бухгалтерському обліку - спеціалізоване програмне забезпечення (далі - П3) ЕRР-класу. Таке ПЗ переважно встановлюється на персональний комп'ютер. Користувач має можливість створювати різнотипні рахунки, накладні, звіти. Будь-які події, які мають значення для управління економікою підприємства, можуть бути зафіксовані у відповідних електронних документах. Більшість варіантів спеціалізованого ПЗ дозволяють формувати аналітичні звіти, розраховувати певні показники діяльності підприємства. Інколи існує можливість виконувати апроксимацію звітних даних та прогнозувати прибуток та інші показники на майбутні звітні періоди. Такий широкий спектр функцій дозволяє ефективно виконувати всі завдання управлінського обліку, а також автоматизовано формувати всі документи для фінансового обліку. Слід зазначити, що більшість вищезгаданих операцій виконується автоматично та потребує мінімального втручання оператора. Такий підхід значно спрощує та пришвидшує роботу фахівців 3 обліку та зменшує ймовірність появи помилок у звітах [7].

Переваги та недоліки застосування різних інформаційних системи 3 метою автоматизації обліку та управління на вітчизняних підприємствах наведено у табл. 1. 
Таблиця 1

Переваги та недоліки застосування різних інформаційних систем для автоматизації обліку та управління на підприємствах України

\begin{tabular}{|c|c|c|}
\hline $\begin{array}{c}\text { IC/ } \\
\text { перева- } \\
\text { ги, недо- } \\
\text { ліки }\end{array}$ & Зарубіжні IC (SAP, Oracle) & $\begin{array}{c}\text { Вітчизняні IC («MASTER», } \\
\text { «BookKeeper SaaS») }\end{array}$ \\
\hline 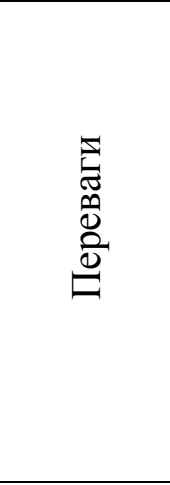 & $\begin{array}{l}\text {-значний світовий досвід розробки та } \\
\text { використання; } \\
\text {-використання найсучасніших техно- } \\
\text { логій; } \\
\text { - світові лідери ЕRР-систем, відомі у } \\
\text { кожній країні; } \\
\text {-велика потужність програмного за- } \\
\text { безпечення; } \\
\text { - найкращий варіант для транснаціо- } \\
\text { нальних компаній. }\end{array}$ & $\begin{array}{l}\text { - підтримка та документація укра- } \\
\text { їнською мовою; } \\
\text {-досить проста експлуатація та ін- } \\
\text { теграція; } \\
\text {-врахування специфіки обліку на } \\
\text { вітчизняних підприємствах; } \\
\text { - порівняно невелика вартість; } \\
\text {-підтримка вітчизняних розроб- } \\
\text { ників програмного забезпечення. }\end{array}$ \\
\hline 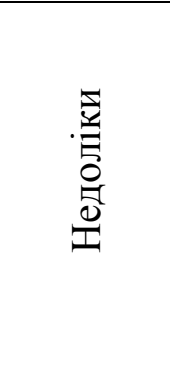 & $\begin{array}{l}\text {-висока вартість програмного забез- } \\
\text { печення; } \\
\text {-досить значна складність експлуата- } \\
\text { ції; } \\
\text {-відсутність офіційної підтримки } \\
\text { українською мовою. }\end{array}$ & $\begin{array}{l}\text {-менша потужність програмного } \\
\text { забезпечення; } \\
\text {-відсутність найновіших техноло- } \\
\text { гій та великого досвіду розробки; } \\
\text {-не надто широке використання } \\
\text { (на поточний час); } \\
\text {-проблематичне застосування у } \\
\text { транснаціональних компаніях. }\end{array}$ \\
\hline
\end{tabular}

Джерело: складено авторами на основі [8 - 12]

В Україні з кінця 1990-х та до 2017 року широкого застосування набуло програмне забезпечення виробництва компанії «1С». Даний програмний продукт особливо часто використовувався на малих та середніх підприємствах. Відповідно до Рішення Ради національної безпеки і оборони України від 28 квітня 2017 року «Про застосування персональних спеціальних економічних та інших обмежувальних заходів (санкцій)» до санкційного списку потрапили ТОВ «1С» та дочірня компанія ДП «Сврософтпром» [2]. Заборона на користування продукцією «1С» стосується державних підприємств, за недотримання наказу передбачаються штрафи. У той же час значна частина приватних підприємств продовжують користуватися П3 «1С» [10].
Зазначимо, що функціонал ERPсистеми «1С» (версії 8.0-8.3) переважно задовольняє вимоги автоматизації обліку підприємства. ERP-система «1C» побудована за принципом технологічної платформи, містить фінансовий контур, бухгалтерський контур, контур логістики, контур управління персоналом, контур управління виробництвом, відкрита для модифікацій за вимогами користувачів та дозволяє завантажувати конфігурації, адаптовані під кожне окреме виробництво. Крім того, програмні продукти лінійки «1С» постійно оновлюються у відповідності до змін законодавства України [10].

До найбільш відомих зарубіжних виробників інформаційних систем для автоматизації обліку та управління 
підприємством належать німецька компанія SAP та американська Oracle.

Система обліку SAP R/3 створена на основі МСФЗ та розміщена у модулі SAP ERP Financials. Модульність програмного забезпечення SAP $є$ однією 3 найбільших переваг розробок SAP та дозволяє легко оновлювати окремі компоненти ПЗ без суттєвих змін всієї IC. Інструменти вказаного модуля SAP дозволяють будувати плани рахунків (оперативний, альтернативний, корпоративний); розрізняти фінансовий та календарний рік; утримувати 3 паралельні курси валют; оцінювати основні засоби підприємства; змінювати форму фінансових звітів (зокрема, Баланс та Звіт про прибутку і збитки); фільтрувати, конвертувати, консолідувати дані. Крім того, SAP певним чином передбачає регіональну специфіку ведення обліку: в модулі SAP ERP Financials передбачений інструмент «спеціальних регістрів», за допомогою яких можна довільним чином модифікувати дані. Наприклад, 3 використанням спеціальних регістрів можна враховувати операції, які релевантні для українського обліку, але не для МСФЗ. Таким чином, SAP R/3 надає необхідний функціонал для ефективного ведення обліку на підприємствах України [9].

Пропоноване комплексне рішення Oracle Applications побудоване не на основі принципу модульності, а як пов'язана система окремих застосунків. Основний застосунок Oracle EBusiness Suite, який забезпечує ведення обліку - Oracle Hyperion Financial Management. Система обліку, як і у випадку SAP, створена на основі МСФ3. Спосіб обліку (як і у SAP ERP) - паралельний. Інструментарій Oracle ERP дозволяє формувати великий спектр облікових документів. Однією 3 переваг застосунків від Oracle $\epsilon$ наявність серверного підходу, що і є характерним для ПЗ вказаного розробника, адже одним з напрямків роботи Oracle $\epsilon$ розробка професійної СУБД. Програмний комплекс Oracle Applications надає один 3 найповніших переліків можливостей для ефективного управління підприємством. Але регіональна специфіка враховується меншим чином, ніж у SAP ERP, тому доводиться розробляти окремі спеціальні конфігурації, адаптовані під місцеві стандарти. Відповідно, придбання та впровадження Oracle ERP на підприємстві коштує більше, ніж впровадження SAP ERP [10].

Ринок українських IC для автоматизації обліку та управління на підприємствах є досить молодим. Розглянемо програмні продукти, які найчастіше використовуються на вітчизняних підприємствах.

Однією з таких інформаційних систем $\epsilon$ «MASTER», яка $є$ типовим прикладом українських ERP-систем. IIÏ створено у 2017 році та побудовано за модульним принципом. Лінійка ПЗ «MASTER» складається із різних компонентів, які охоплюють майже всі контури господарської діяльності підприємства. Серед таких компонентів: «MASTER:Бухгалтерія», «MASTER: Агро», «MASTER:Зарплата і Кадри», «MASTER:Документообіг», «MASTER: Бізнес», «MASTER: Комплексний облік для бюджетних установ» [11]. Модуль операцій «Продажі» дозволяє відстежувати торгівельні операції підприємства, створювати та друкувати відповідні рахунки, вести облік доходів. Крім того, наявна можливість враховувати повернення товару. Модуль операцій «Покупки» до- 
зволяє відстежувати всі придбані товари та послуги підприємством, а також вести відповідний облік витрат. Окремий модуль дозволяє вести облік складських приміщень підприємства, проводити інвентаризацію. Модуль «Виробництво» відстежує процес ведення виробництва, веде облік завершеного та незавершеного виробництв. У модулі «Основні засоби та необоротні матеріальні активи» реалізовано ведення обліку основних засобів та нематеріальних активів. Наявні також модулі «Кадри» та «Зарплата», у яких можна зберігати всю необхідну інформацію про персонал, а також вести облік витрат на оплату праці (враховуються окремо всі податки, збори та інше). Для ручних операцій передбачено модуль «Операції». Таким чином, функціональність П3 «MASTER» повністю забезпечує потреби підприємства для автоматизації діяльності. Усі аналітичні форми, типові звіти повністю відповідають чинному законодавству України та регулярно оновлюються. Вартість ПЗ досить помірна (так, вартість комплекту «MASTER: Бухгалтерія» та «MASTER:Зарплата i Кадри» станом на травень 2020 становила 17999 грн) [11].

«BookKeeper SaaS» - українська онлайн-платформа для ведення обліку. Характерною особливістю цієї IC $є$ те, шо вона повністю базується на хмарних технологіях. Перевагами такого підходу є відсутність необхідності наявності конкретного апаратного забезпечення, можливість входу до системи 3 будь-якої технологічної платформи (підтримуються Windows, Linux, Mac OS), захищеність даних, бюджетність рішення (вартість щомісячного внеску станом на травень 2020 складала 295 грн). При цьому IC підтримує усі основні операції ведення обліку, такі як: облік придбань (основні рахунки, накладні, повернення); облік продажів (залишки, прайс-листи, базові накладні); облік запасів (інвентаризація, виробництво, списання); облік валютних операцій; облік персоналу (звіти про прийняття та звільнення, облік витрат на оплату праці); ведення базової звітності та ін. Крім того, наявна можливість відправляти податкову звітність безпосередньо з сервера через програму «Соната» (основна програма електронного оподаткування). Звісно, повний функціонал IC дещо менший, ніж у провідних ЕRP-систем іноземних розробників, але IC «BookKeeper SaaS» орієнтується саме на вітчизняні малі підприємства та ФОП [12].

Зупинимось більш детально на використанні хмарних технологій для автоматизації обліку та управління економічною безпекою підприємств. «Хмарні обчислення (хмарні технологіï) - це технологія розподіленої обробки даних, в якій комп'ютерні ресурси і потужності надаються користувачеві як інтернет-сервіс. Хмара - це нова технологія використання серверних ресурсів, що допомагає задіяти всю доступну потужність процесорів i об'єм оперативної пам'яті, розподіляючи їх між різними незалежними завданнями» [13]. Хмарні технології реалізуються за трьома моделями, але найпростішою і найбільш поширеною у використанні технологією для автоматизації обліку $є$ «програмне забезпечення як послуга» (SaaS - software as a service), яка полягає у наданні послуги користування певним програмним забезпеченням через мережу Iнтернет (найчастіше, за рахунок щомісячних платежів). Саме ця технологія 
використовується

«BookKeeper SaaS».

системою

Найчастіше SaaS-технологіï мають такі сфери застосування: сервіси зберігання даних (Dropbox, диск Google), онлайн-офіси (GoogleDocs), онлайн бухгалтерія (BookKeeper Saas), спеціалізовані Інтернет-додатки, закриті хмари [14].

В Україні інтеграція хмарних технологій перебуває на початковому етапі та полягає у систематизації та аналізу аналогічного успішного досвіду зарубіжних країн. Але стрімкий розвиток інформаційних технологій у всьому світі сприяє розробці хмарних застосунків українськими розробниками, вже з'являються перші рішення, зокрема була розроблена інформаційна система «BookKeeper SaaS» [14].

Можемо констатувати, що хмарні технології $\epsilon$ надзвичайно перспективними технологіями, які набудуть ще більш широкого застосування у майбутньому. Хмарні технології можна ефективно використовувати для реалізації інформаційних систем 3 метою автоматизації бухгалтерського обліку, внутрішнього контролю, управління фінансовою, інформаційною безпекою підприємств та вдосконалення його функціонування в цілому.

Висновки. Автоматизація ведення бухгалтерського обліку та управління економічною безпекою підприємств є сучасною тенденцією, яка не втратить своєї актуальності, враховуючи глобальну діджиталізацію та розвиток безконтактної економіки. Застосування інформаційних систем для автоматизації обліку та управління надає ряд переваг підприємству, серед яких спрощення, зниження трудомісткості ведення обліку та аналізу інформації, зменшення ризику помилок фахівців при обробці даних. При цьому має місце складність інтеграції інформаційних систем у діяльність підприємств та проблема безпеки даних. Тому до інформаційних систем користувачами висуватимуться усе більші вимоги щодо забезпечення захисту даних, недопущення їх втрати внаслідок кібератак та ненадійності системи, підвищення рівня інформаційної безпеки підприємства. У той же час ефективне використання сучасних інформаційних технологій та систем для ведення обліку та управління економічною безпекою можливе за умови наявності цифрових навичок у бухгалтерів підприємства та їх постійного вдосконалення в умовах модернізації програмного забезпечення. Саме тому особлива увага має бути приділена формуванню цифрової грамотності фахівців у сфері бухгалтерського обліку та оволодіння ними навичками використання найсучаснішого спеціалізованого програмного забезпечення, яке автоматизує ведення обліку та управління суб'єктами господарювання.

Найбільшого застосування у корпоративному секторі набуло програмне забезпечення ERP-класу, яке характеризується фундаментальним системним підходом та здатне задовольнити не тільки вимоги користувачів для ведення обліку, а й управління підприємством в цілому.

Вітчизняний ринок ERP-систем стрімко розвивається і пропонує конкретні рішення для автоматизації обліку та управління підприємством. Найбільш перспективними технологіями автоматизації обліку та управління підприємством $є$ хмарні технології. Застосування цих технологій вирішує проблему дефіциту потужності ресурсної бази підприємства, а також висо- 
кої вартості програмного забезпечення ERP-класу.

\section{Список використаної літератури}

1. Офіційний сайт Державної служби статистики України. URL : http://www.ukrstat.gov.ua/ (дата звернення : 17.07.2020).

2. Про застосування персональних спеціальних економічних та інших обмежувальних заходів (санкцій). Рішення Ради національної безпеки і оборони України від 28 квітня 2017 року. URL : https://zakon.rada.gov.ua/ laws/show/n0004525-17\#Text (дата звернення : 17.07.2020).

3. Щедрин А.Н. Электронные информационные ресурсы в информационной экономике: Монография. Науч. ред. А.И. Амоша. Д.: Ин-т экономики пром-сти НАН Украины, 2003. 232 с.

4. Інформаційні системи і технології в економіці: посібник/ за ред. В.С. Пономаренка. К.: Академія, 2002. 544 с.

5. Leon, Alexis. (2008). Enterprise Resource Planning, 2nd. New Dehli: McGrawHill. 500 p.

6. Кулинич М., Шворак А., Жиленко Л. Впровадження цифрової грамотності в умовах майбутніх змін професії бухгалтера. Економічний часопис Східноєвропейського національного університету імені Лесі Украйнки. 2020. № 1 (21). С. 216-224.

7. Онищенко О.В. Упровадження та застосування сучасних інформаційних технологій і ERP-систем у бухгалтерському обліку вітчизняних підприємств. Східна Європа: Економіка, Бізнес та Управління. 2019. № 3 (20). С. 515-522.

8. Oracle Cloud. URL: www.oracle.com/ (дата звернення 27.07.2020).

9. SAP has the solutions to help you. URL : www.sap.com/ (дата звернення : 17.07.2020).

10. Черножукова А.М., Лободзинська Т.П. Порівняльний аналіз автоматизованих систем бухгалтерського обліку на підприємствах України. Ефективна економіка. 2017. № 6. URL : http://www.economy.nayka.com.ua/?op=1\&z=5661/ (дата звернення : 17.07.2020).

11. MASTER Бухгалтерія. URL : www.masterbuh.com/ (дата звернення 27.07.2020).

12. BOOKKEEPER Українська онлайн бухгалтерія. URL : www.bookkeeper.kiev.ua/ (дата звернення : 17.07.2020). 
13. Шкарлет С.М., Бутко М.П., Волот О.І. Реальний сектор економіки України в умовах становлення інформаційного суспільства: монографія. Чернігів: ЧНТУ, 2017. 288 с.

14. Волот О.І. Застосування хмарних технологій в обліку та управлінні підприємствами реального сектору економіки. Центральноукраӥнський науковий вісник. Економічні науки. 2019.№ 2 (35). С. 190-198. 